\title{
Recent Advances in the Chemistry of Bioactive Compounds from Plants and Soil Microbes: a Review
}

\author{
Abdurrashid Haruna $^{1}\left(\mathbb{0} \cdot\right.$ Sharhabil Musa Yahaya ${ }^{2}$ \\ Received: 5 August 2020 / Accepted: 3 December 2020 / Published online: 8 February 2021 \\ (c) The Tunisian Chemical Society and Springer Nature Switzerland AG 2021
}

\begin{abstract}
Bioactive compounds derived from plants and microbial sources are required for the survival of the human race and groundbreaking research must continue in this line. Plants and microbes are the major sources of naturally occurring bioactive compounds for numerous biotechnological applications. Recent progress in the fields of bioactive compounds and soil chemistry in agriculture has since given man a lead to the discovery of potent drugs that combat both human and plant diseases. The soil provides the medium for the growth of medicinal plants, but its contamination greatly affects the quality of drugs, food crops, and other essential elements present in the plants which give strength to the body. This area has attracted the attention of scientists and the drug industry toward developing more potent drugs from medicinal plants grown in different soil. The studies of the effect of various parameters and the properties of soil such as; effect of heavy metals, $\mathrm{pH}$, soil organic matter, and phytoremediation process have given a measure of some quality dependence of the soil producing secondary metabolites and soil containing microbes. The information provided will be useful in determine the action of microbes and their interaction with the soil and all true plants producing drugs. Some active compounds in plants and microbes, their properties, and applications have been described in this review. The soil microbes, activities and their interactions, effects of soil particle size, dispersibility and stability of microbes in the soil, and the future outlook for the development of novel active compounds have been reported.
\end{abstract}

Keywords Bioactive compounds $\cdot$ Soil properties $\cdot$ Secondary metabolites $\cdot$ Soil microbes $\cdot$ Drug discovery

\section{Introduction}

Chemistry in agriculture is a growing area of interest in modern technology particularly in the areas of drug development and food quality for many human purposes. Plants grown in the soil form the major potential sources of medicine of high therapeutic value in the form of secondary metabolites that are used in the treatment of various diseases [1-4]. The studies of the different part of plant (leaves, roots, barks, fruits and seeds) have led to the discovery of numerous biologically active drugs. A great deal of attention has been paid to the resistive nature and causes of the decrease in the mechanism of action of the phytoconstituents present

Abdurrashid Haruna

abdurrashid.haruna@yahoo.com

1 Department of Chemistry, Ahmadu Bello University, Zaria, Nigeria

2 Department of Soil Science, Ahmadu Bello University, Zaria, Nigeria in plants. Soil contamination tends to affect medicinal plants and other agricultural products grown in the soil. The growing resistance of pathogens against the already known drugs has called for a research to find out the effects responsible for the lessening of the chemical activity of drugs isolated from these medicinal plants [5]. The need for new and more active antibiotics to fight multidrug-resistant microbial pathogens is therefore necessary [6]. To begin with, the discovery of a well-known anti-malarial drug, quinine, is a particularly good example (Fig. 1) which in recent times have been found to possess a decrease in its chemical activity. Among numerous other reasons why some microorganisms and bacteria developed resistance against drugs in this century is the presence of toxic heavy metals in the soil such as cadmium, mercury, lead, chromium, arsenic, nickel, copper and zinc [7].

Heavy metals at high concentration causes soil toxicity and affects soil performance by reducing the availability of important mineral elements present in the soil. Some of the active components in plants are affected this way, enzyme 
(a)<smiles>c1ccc2ncccc2c1</smiles>

Quinoline<smiles>[1H]Cc1ccnc2ccccc12</smiles>

Lepidine<smiles>COc1ccc2ncccc2c1</smiles>

6-Methoxyquinoline<smiles>C=CC1CC2CCN(C2)[C@H]([C@H](O)c2ccnc3ccccc23)C1</smiles>

Cinchonine<smiles>C=CC1CC[C@@H]([C@H](O)[C@H](O)c2ccnc3ccc(OC)cc23)N(CC2CCC2)C1</smiles><smiles>C=CC1CN2CCC1C[C@H]2[C@H](O)c1ccnc2ccccc12</smiles>

Cinchonidine

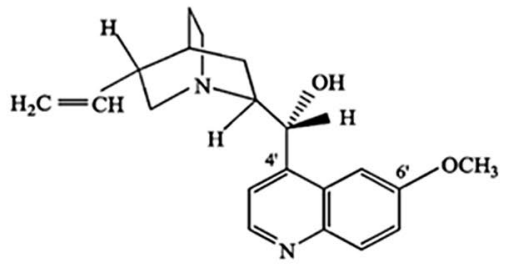

Quinine (b)
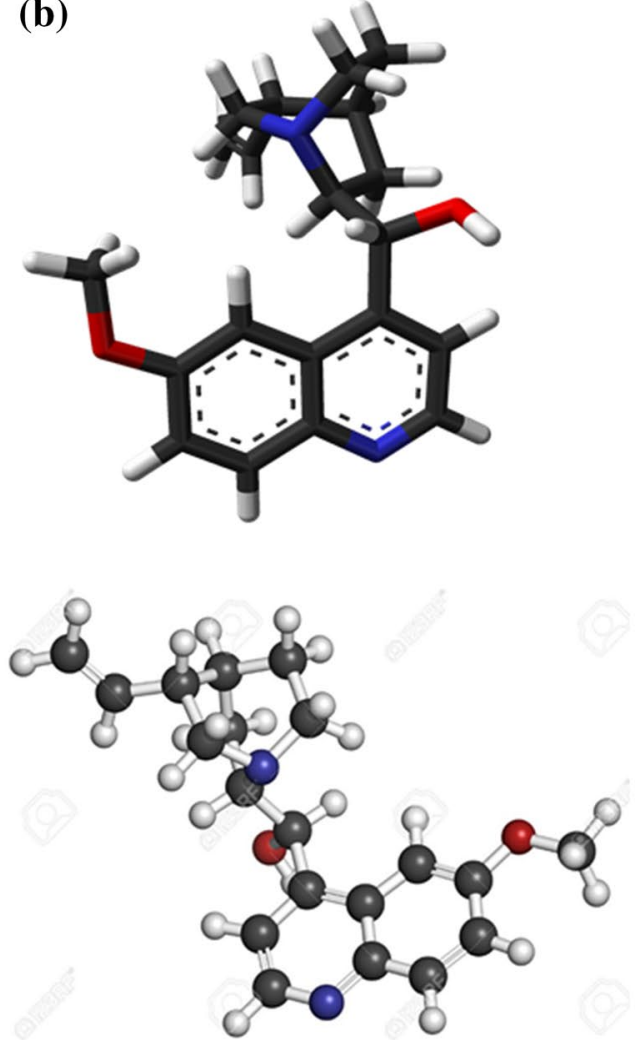

Fig. 1 a Quinine and some derivatives, b 3-D sticks and ball model structures of quinine. Reprinted with permission from Reference [20, 21]

activity is weaken, and the soil microorganisms are significantly reduced $[8,9]$. A large deposit of heavy metals in the soil may come due to the various human activities including waste disposal, industrial sewage release, weapon testing by the military, application of fertilizers, smelting and metallurgy, painting, tanning process, mining and oil exploration activities. Although, soil microbes may use heavy metals in the soil for their metabolic action and growth, through good utilization of the metals via electron transfer process. But when at high concentration, the metals greatly affect their life cycle. Reports have shown anaerobic bacteria to be capable of removing contaminants from farm lands affected by crude-oil spillage [10]. Also, the soil microorganisms aid the recycling of the soil organic matter (SOM), reworking and mineralizing the organic residues into useful substances; sulphur, nitrogen, phosphorus, carbon dioxide and water, and other nutrients needed by the plants to improve its overall quality [11].

Most soils especially in Africa, contain low percentage of organic matter. The SOM consists of important chemical compounds like the alkyl aromatics, phenols, carbohydrates, peptides, hydrocarbons, lipids, sterols, lignins, bound and free fatty acids, nitriles, and suberin [12]. SOM also help in the physical protection of the soil, root development, microbial activity and for the prevention of erosion
[13]. Soil health and quality are assessed using some prime indicators which include the effect of $\mathrm{pH}$, and nanoparticles (NPs) dispersed in the soil depending on specific use of the land. Addition of fertilizers in various agricultural fields affects both the plants and soil $\mathrm{pH}$. Soil $\mathrm{pH}$ then affects the availability of plant nutrients, medicinal value, quality of food crops, and the overall activity of microorganisms. Most plants will require a $\mathrm{pH}$ range of 6-7.5 for optimal growth, less toxicity with the high expectation of medicinal value. NPs nowadays are used for plant protection and their release into the agricultural soil affects the performance of soil microorganisms $[14,15]$. For instance, $\mathrm{TiO}_{2}$ and $\mathrm{CuO} \mathrm{NPs}$, are applied in the soil to cause decay in bacterial growth, and to reduce multiplicity of soil microorganisms $[16,17]$. Again, the microorganisms in soil respond to different type of NPs due to some other factors, which include the quantity, time, inherent toxicity, experimental conditions, treated microbiological species, and other soil properties ( $\mathrm{pH}, \mathrm{SOM}$, water content, iron strength) [18].

Large numbers of opportunities have opened up recently in the discovery of novel compounds isolated from microbial and plant sources, including the new chemical approach of manufacturing bioactive metabolites from bacteria which are developed into drugs. The bioactive compounds of plants and microorganisms are 
continually explored for the discovery of new drugs worldwide. Man will not rest in search of natural products because some of these microorganisms live together with the plants in the different parts under natural environments thereby creating a strong relationship. This relationship between microorganisms and plants has grown and many bioactive compounds are now used as medicines. The growth of knowledge in this area is increasing at an accelerating pace and a large number of naturally derived drugs are known and isolated every day. It is worthy to note that, this field has become a rewarding scientific effort in investigating bioactive molecules from microbes that are used in finding new specialized metabolites [19]. The soil characteristics and microbial activity could lead to the determination of soil quality, enzyme activity and biological situation used as indicators for measuring the activity of isolated compounds. A new dimension of research to achieving this should involve the application of NPs, computational and optimization of molecules, their molecular docking studies, dynamic simulation, and drug design. This area is particularly interesting because it makes work easier for scientists in studying the properties of compounds, calculating the energy and other thermodynamic parameters and this altogether is believed to be the promise of future drugs. It should be noted however, that isolation of natural products has dramatically changed due to the advent of computational chemistry. This review covers the summary of the recent progress of some bioactive compounds, properties, influence and their various applications. It also analyzes soil microbial activities, their interactions, effects of soil particle size, dispersibility and stability of soil microbes and the future perspective for the development of bioactive chemical compounds.

\section{Properties of Active Compounds and Applications}

Natural products derived from plants and microbial sources are known over the years, and their unending applications in drug discovery and development remained very promising. The different parts of diverse plant species have demonstrated the essential sources of novel drugs in the treatment of malaria, cancer, heart diseases, fungal, and bacterial infections. The phytochemical studies of plants over the years have indicated the presence of flavonoids, alkaloids, tannins, saponins, and glycosides in medicinal plants. They constitute most of the active ingredients present in the plants for the overall benefits of man and plants as shown in Table 1. These phytochemicals, especially in high concentrations, can protect the plants from free radical damage and hyperaccumulation. This will also enable the plant to produce a variety of diverse bioactive compounds for use in the treatment of harmful diseases. Plants containing positive phytochemicals form the rich source of antioxidants which increase value to the total health and well-being of humankind [22]. Phytochemicals also perform voluminous biological and physiological functions and are widely distributed in diverse plant species. Reports have shown the extracts of most plant species to be active against different pathogenic microorganisms; such as Candida albicans, Escherichia coli, Pseudomonas aeruginosa, Salmonella typhi, Staphylococcus aureus, and Bacillus subtilis [23]. Some of these microorganisms are more susceptible and give the highest zone of inhibition than others based on their classification as either Gram-negative or Gram-positive species [24]. Table 2 shows the zone of inhibition for the growth of plant extracts against some tests organisms namely; $S$. aureus, S. typhi, E. coli, C. albicans, and C. tropicalis to study the interaction between the various plants extracts with
Table 1 Phytochemical composition of different part of plant species used for traditional medicine

\begin{tabular}{lllllll}
\hline Study & Plants & \multicolumn{3}{l}{ Phytochemicals } & & \\
\cline { 3 - 7 } & & Alkaloid & Flavanoids & Saponins & Tannins & Glycosides \\
\hline$[28]$ & Talinum triangulare & + & + & + & + & - \\
{$[29]$} & Vernonia ambigua & + & + & + & + & + \\
{$[30]$} & Indigofera conferta & + & + & + & + & - \\
{$[25]$} & Lantana camara & - & + & + & + & + \\
{$[31]$} & Coula edulis & - & + & + & + & + \\
& Pseudospondias longifolia & - & + & + & + & + \\
& Carapa klaineana & - & + & + & + & + \\
{$[32]$} & Lophira procera & + & + & + & + & + \\
{$[33]$} & Tulbaghia species & - & + & + & + & + \\
{$[34]$} & Distemonanthus benthamianus & + & + & + & + & + \\
{$[35]$} & Mangroves plants & - & + & + & + & + \\
\hline
\end{tabular}

Key $=+($ present $),-($ Absent $)$ 
Table 2 Antimicrobial screening of some selected plant extract species showing the zone of inhibition (mm)

\begin{tabular}{lllllll}
\hline Study & Plants extracts & \multicolumn{6}{l}{ Test organism } & & \\
\cline { 3 - 6 } & & S. aureus & S. typhi & E. coli & C. albicans & C. tropicalis \\
\hline$[36]$ & Anisopus mannii & 24 & 06 & 06 & 22 & 20 \\
{$[30]$} & Indigofera conferta & 30 & - & 18 & 16 & $\mathrm{Nd}$ \\
{$[31]$} & Coula edulis & 13 & 8 & 12 & 10 & $\mathrm{Nd}$ \\
& Pseudospondias longifolia & 9 & 8 & 7 & 10 & $\mathrm{Nd}$ \\
& Carapa klaineana & 7 & $\mathrm{Nd}$ & 8 & 8 & $\mathrm{Nd}$ \\
{$[31]$} & Distemonanthus benthamianus & 9 & 11 & 9 & 7 & $\mathrm{Nd}$ \\
\hline
\end{tabular}

$N d$ not determined the microorganisms. The zone of inhibition gives a measure of determining if a particular plant extract is active or not against a specific microorganism but the minimum inhibitory concentration (MIC) gives the correct measure of the potency of the extracts at a stated concentration (in absolute standard unit) and is usually compare with a standard drug. To find out if the extracts can destroy the microorganism, a test of minimum bactericidal concentration (MBC) is usually carried out.

Some antibiotics produced from medicinal plants come with a series of unwanted side effects that limits their applications. Most of the microorganisms causing diarrhea, cutaneous and urinary infections, and other respiratory diseases are currently developing resistance. This is mostly due to the indiscriminate use of antimicrobial drugs for the treatment of ailments. The need to understand the mechanisms of action of microorganisms toward developing new antimicrobial agents that are active with reduced side effects is necessary [25]. Chemical compounds isolated from the extract of plant species also find application in the treatment of cancerous cells, chickenpox, measles, asthma, ulcers, swellings, eczema, tumors, and high blood pressure. They are also used to cure fevers, tetanus, rheumatism, and malaria. The different plant extracts of medicinal values also possess insecticidal, and nematicidal activity in addition to verbascoside that has a combination of both antimicrobial, and antitumor activities [26, 27]. Some factors such as the effect of nanoparticles, heavy metals, soil organic matter, and $\mathrm{pH}$ affecting medicinal plants, microbial activities in the soil, their cultural practices, and their various influences on microbial biomass are briefly discussed.

\subsection{Effect of Nanoparticles}

Nanoparticles greatly affect the structure and function of microorganisms in the soil but little information has been reported so far [37]. NPs have a potential impact on the toxicity of microorganisms thus hugely affected by their size, shape, and concentration [38]. For instance, silver nanoparticles (AgNPs) released into agricultural land may impact soil microbial activity and diversity, also their toxicological effects may be specific to microbial species [39, 40]. Soil microorganisms are the key players in nutrient cycling, fixing nitrogen to the plants and are indispensable to the soil ecosystem [41]. Wastewater treated by NPs, are used in agricultural farmlands to enhance the nutritional value of medicinal plants [42]. Reports have shown that soil microorganisms influenced by the building-up of AgNPs in the soil are used to decrease the bacterial abundance [43, 44]. In another development, soil properties and structure, as well as bacterial phyla may change due to the varieties of NPs [45]. Some NPs even harm the microbial community composition of activated sludge, especially on the abundance of nitrifying bacteria which also negatively changed the metabolic activity of soil microbes [46]. In recent technology, however, NPs synthesized by plants can be used to remove metal toxicity through the bioaccumulation process.

\subsection{Effect of Heavy Metals}

Soil contamination with toxic heavy metals by various human activities is a critical environmental problem in both developing and developed countries. Heavy metals introduced into medicinal plants through contaminated soil, water, and other elements may lead to serious problems for the plant. The growing of medicinal plants in heavy metal polluted environments may eventually affect the biosynthesis of secondary metabolites, causing significant changes in the quantity and quality of the bioactive compounds presents [47]. Heavy metals are capable of reducing the enzyme activities in the soil as a result of soil pollution. Several studies have reported the relevance of microorganisms in soil and the effect of heavy metals concerning the contamination processes which disrupt their ecosystem [48]. This is due to the complex interaction between the chemical pollutants and the microbial biomass that exist among the different types of soil [49]. The effect of heavy metals on medicinal plants producing drugs is monitored by the action of The amount of heavy metals may influence the soil properties such as the soil type, soil $\mathrm{pH}$ and salinity which significantly affect the soil microbial biomass and their activities [50, 51]. Bacteria, fungi, and Protista are the type of microorganisms that 
can degrade or remove heavy metal compounds effectively and transform the end-product into part of their metabolism for use by the plants with the aid of specialized enzymes. Microorganisms and secondary metabolites in plants have been reported to stabilize and reduce metal ions into NPs [52]. The NPs with the active compounds can form a stable complex which if harnessed has the potential for drug discovery and in the harvesting of other precious molecules.

\subsection{Soil Organic Matter}

From the environmental point of view, the application of organic matter into the soil helps to increase the microbial biomass and the plant nutrients. The physical and chemical properties of soil and the availability of nutrients for the plant and microbial growth is hugely influenced by the SOM. The decrease in the SOM content, however, directly affects the microbial biodiversity and this has some advantage in the sustainability of the plant over the use of chemical fertilizers. The organic matter composed of the animal dung and feces, their compost and crop residues to soil usually increase the soil biomass and their activities. The relationship between the quantity of organic matter and soil biomass applied in the soils is amended with the various organic materials. The use of inorganic fertilizer may not be as good as the effect of application of organic material in the soil for the plant growth and its medicinal value. Soil microbial populations tend to increase by the addition of animal manures or by synthetic fertilizers where crop residue production and soil organic matter levels are simultaneously increased. SOM can either be active or passive, fast in recycling or based on humic fraction which can remain in the soil for years [13].

\subsection{Effect of pH}

Soil $\mathrm{pH}$ is an important variable in producing medicinal plants of high value from which active drugs are isolated. It can be used to determine the effect of the microbial community in soil, enzyme activity and microbial distribution. For instance, Khamna et al. [53] reported the effect of $\mathrm{pH}$ on enzyme system, stability and solubility of many important substances that aid bacterial growth on soils. Contaminants and other pollutants in the soil can also be removed by the phytoremediation process, a technology of emerging interest in the field of environmental remediation [48].

\subsection{Phytoremediation}

Different plant species that accumulate heavy metals have been found very useful in the decontamination of metalpolluted soils through the phytoremediation process. Phytoremediation is a cheap technology of removing pollutants from plants to enhance its quality and medicinal value by the conversion of sunlight energy into chemical energy [54]. The high concentration of heavy metal in the soil that deeply affects the soil microbes and their activities, play an important role in the phytoremediation of heavy metals [55]. Again, the soil microorganisms are used for the remediation of heavy metals in our environments. They are able to achieve this because of the physiological mechanisms they display which allow them to tolerate and utilize heavy metals in their systems for metabolic action [48].

\section{Bioactive Compounds from Medicinal Plants}

Bioactive compounds derived from different plant species of medicinal value are active against microorganisms and parasitic infections [56]. Bioactive compounds are present in over 400, 000 different plant species worldwide but only a little fraction of these huge numbers have been explored in the scientific community [57]. They are screened and isolated via rigorous scientific analyses and characterizations to investigate and determine their therapeutic properties [58]. Good numbers of the chemical compounds derived from plants and microorganisms are made available as drugs for clinical uses during the process of drug discovery as presented in Fig. 2. Extensive studies of these natural products and their derivatives have given a lead to drug discovery of high therapeutic values. Bioactive compounds can also be synthesized in different pathways, but their mechanism of action differ significantly from those derived from plant materials. In its entirety therefore, the bioactive compounds have revolutionized the medicinal world.

The antitumoral, antifungal, anticancer, antimalarial and antibacterial drugs have been known and discovered from medicinal plants in the past decades [59-61]. However, the fungal pathogens have grown resistance overtime against the antifungal drugs during the last $10-15$ years. Due to this reason, the importance to harness the benefits of other medicinal plants has increased because of their potential activities [62]. In another development, various important drugs such as morphine, cocaine, quinine, and codeine isolated from medicinal plants are still in use as painkiller, cough remedies and so on [58]. The discovery of sesquiterpene artemisinin is a breakthrough for the development of antimalarial drugs which can even kill multidrug-resistant strains of Plasmodium falciparum [63]. Table 3 shows the isolated bioactive compound from useful medicinal plants and their applications.

\subsection{Bioactive Compounds from Soil Microbes}

Living organism such as bacteria and fungi produce important biologically active compounds that find wide spectrum 


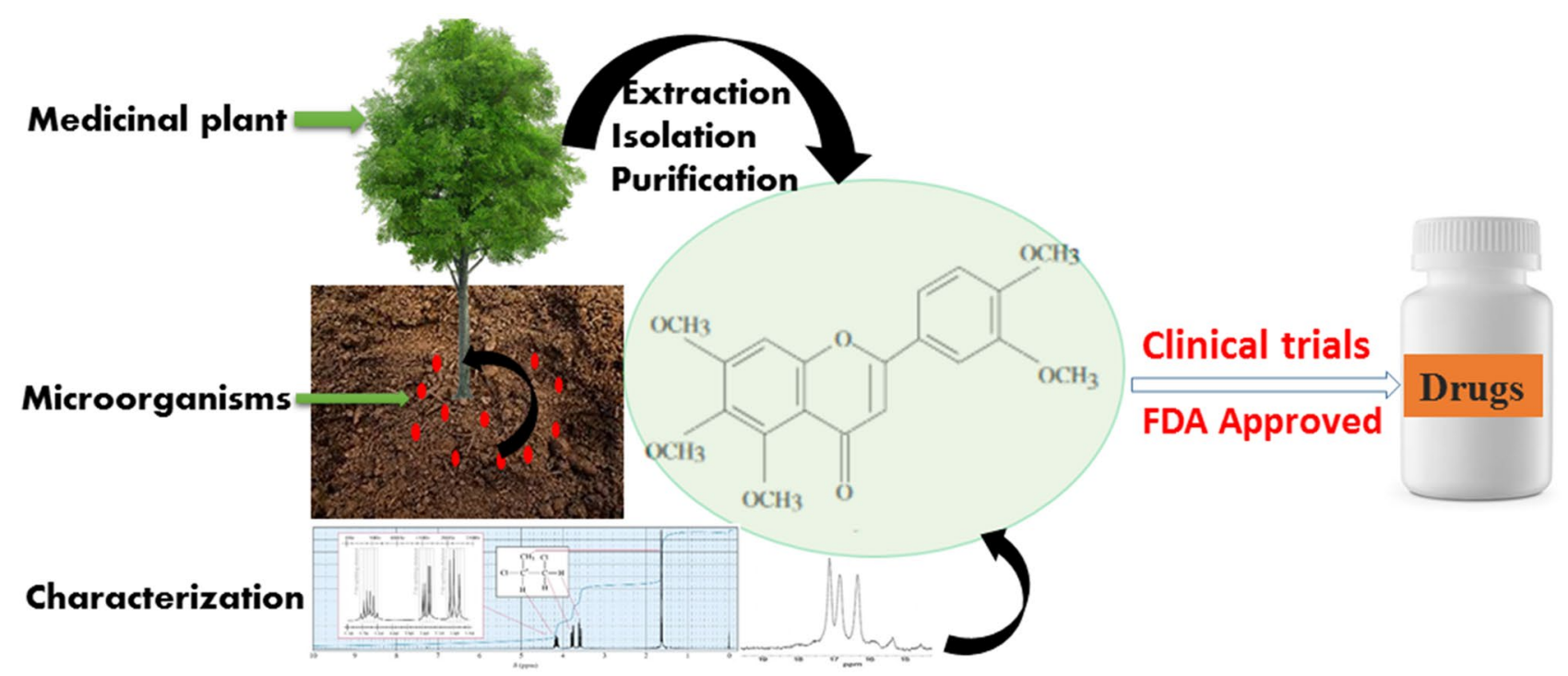

Fig. 2 Methods of bioactive compound determination to the process of drug discovery and approval

of applications as antibiotics to cure diseases [89]. To date and beyond the perception of man, numerous antibiotics isolated from microbial world have been shown to inhibit the growth of other organisms [90]. Certain isolated compounds such as the statins are used in controlling heart diseases whereas cyclosporin and fujimycin are useful as immunosuppressive agents. The Streptomyces in the soil gives more than $70 \%$ of the important antibiotics and agro-antibiotic chemical compounds used in curing diseases [91]. Bioactive compounds such as dibutyl phthalate and eicosane produced by Streptomyces are used for antifungal activity against Rhizoctonia solani [92]. In recent times, the isolation and production of bioactive compounds of microbial origin are on the increasing application in health care. Some bioactive compounds of microbial sources and their applications are reported in Table 4. Most of the isolated compounds have antidiabetic, anticancer, antibacterial, and antifungal activities. A huge number of microbial metabolites have been isolated and screened for the treatment of human diseases.

In another development, bioactive compounds synthesized by microorganisms in association with plants are recently in very high demand for drug manufacture due to their health benefits to both man and plants. Singh et al. [103] reported the production of an array of compounds by microbes inside of plant (endophytes), they produced promising resources of biotechnologically important active compounds and secondary metabolites. The endophytic Streptomyces are also antimicrobial agents that produced novel antibiotics that are effective against multi-drug-resistant bacteria, they are toxic to pathogens and do not harm humans and are very sustainable. Besides their high pharmaceutical applications, they are also used in promoting the growth of plants. Extracellular enzymes like the Hydrolases produced by endophytic bacteria, help the plants to establish systemic resistance against pathogens invasion. Again, the actinomycetes present in the soil are capable of producing bioactive compounds against several phytopathogens [104, 105].

\subsection{The Chemistry of Soil Microbes and Their Interaction}

The relationship between plant and soil microorganisms can be beneficial or harmful to plants. Understanding the interaction of the medicinal plant with microorganisms in respect of their physicochemical environment may provide insights into the microbial ecology of the plant-associated endophytes [106]. These microorganisms live in different parts of the plants forming distinct microbial communities. The endophytic bacteria help in supplying nutrients to the plants such as nitrogen, potassium, iron, and indole acetic acid while the plant provides the endophytes with a stable environment [107, 108]. Some bacteria, fungi, and viruses are pathogenic microbes that cause diseases to the plant. Rhizobium is an important microorganism that helps the plant resist biochemical stress and promote the nutrient and growth of the plant. Duca et al. [109] reported the interaction and relationship between microbes and the active compounds in the soil. Their studies have shown that endophytic bacteria produce plant growth promoters. Nitrogen gas in the air are reduced into nitrogenous compounds and other products in a symbiotic relationship between Rhizobium and Frankia. Also, the absorption capacity of the root and water availability significantly improved the mycorrhizal fungi. The bioactive compounds produced from microbes are 


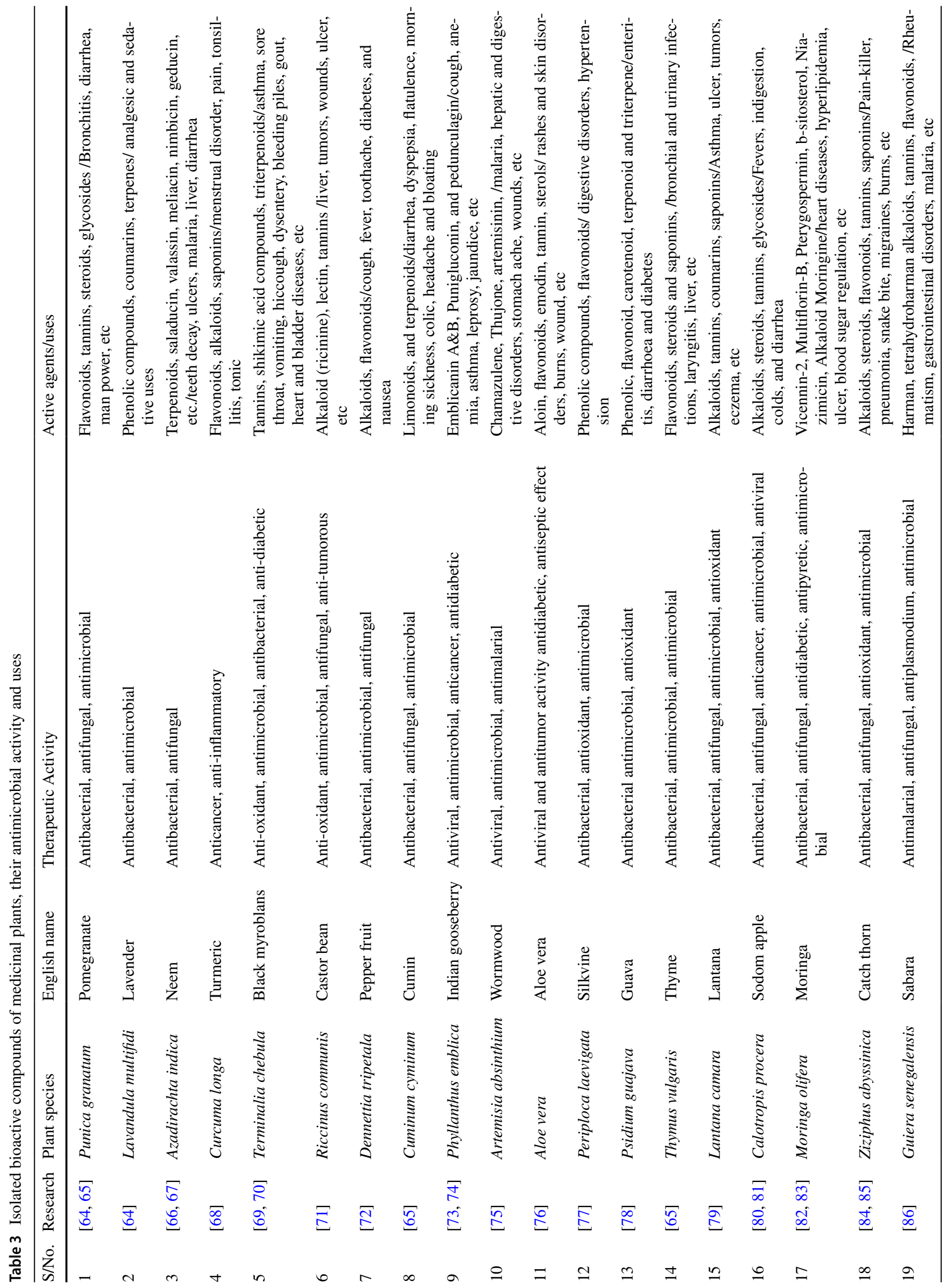


widely used to stimulate plant growth in the form of bio-pesticides, phyto-stimulators, and bio-fertilizers to increase crop yield and to control plant in defense against pathogens. A very important phyto-hormone, Indole-3-acetic acid (IAA), which is produced by diverse species of bacteria, is found beneficial and venomous but has the capacity to control the growth and development of plants. Figure 3 shows the plant and microbial biosynthetic pathways of IAA. The phytopathogens and plant growth promoters synthesized IAA in three basic pathways. They are the indole-3-pyruvic acid, indole-3-acetamide, and indole-3-acetonitrile pathways.

\subsection{Computational Methods to Drug Leads}

The knowledge of computational chemistry has simplified and improved the design of drugs, especially to the pharmaceutical industries through the correct study of the relationship between chemical structure and the bioactivity of molecules [111]. Computational methods of drug improvement are currently taking lead because it minimizes the risk associated with the discovery of potent drugs, shortens the period of screening and searching of bioactive compounds. The knowledge derived from the computational studies is used to support the design of new drugs with high potency. The study employed the use of computational tools for the analysis and modeling of the chemical compounds. Reports have shown that computational tools used in the development of drugs may reduce up to 50\% of the cost [112] and recently some studies in this line have been carried out on quinolone derivatives as anti-tubercular agents against Mycobacterium tuberculosis and the findings suggested the in vitro and in vivo studies be carried out to validate the computational/in silico results [113, 114]. Moreover, it provides theoretical frameworks for researchers in the pharmaceutical field of studies toward synthesizing a modified structure with a better activity [115].

\section{Soil Microbes, Activities and Applications}

Soil microbes also known as soil microorganisms are the living components of the soil ecosystems that comprises of organisms of various sizes which are either large enough to be visible with naked eyes, or too tiny to be only visible with the aid of a microscope. Soil microbes exist in various levels of organization ranging from the cellular level up to the systematic level of organization [116]. The soil organisms are generally classified into major target groups as macrofauna, mesofauna, microflora and microfauna [48]. Macrofauna are those soil organisms that have a diameter greater than $2 \mathrm{~mm}$ and are $1 \mathrm{~cm}$ long, examples; centipedes, millipedes, termites, earthworms, etc. Mesofauna are those soil organisms that are between 0.2 and $2 \mathrm{~mm}$ in size, examples include; 


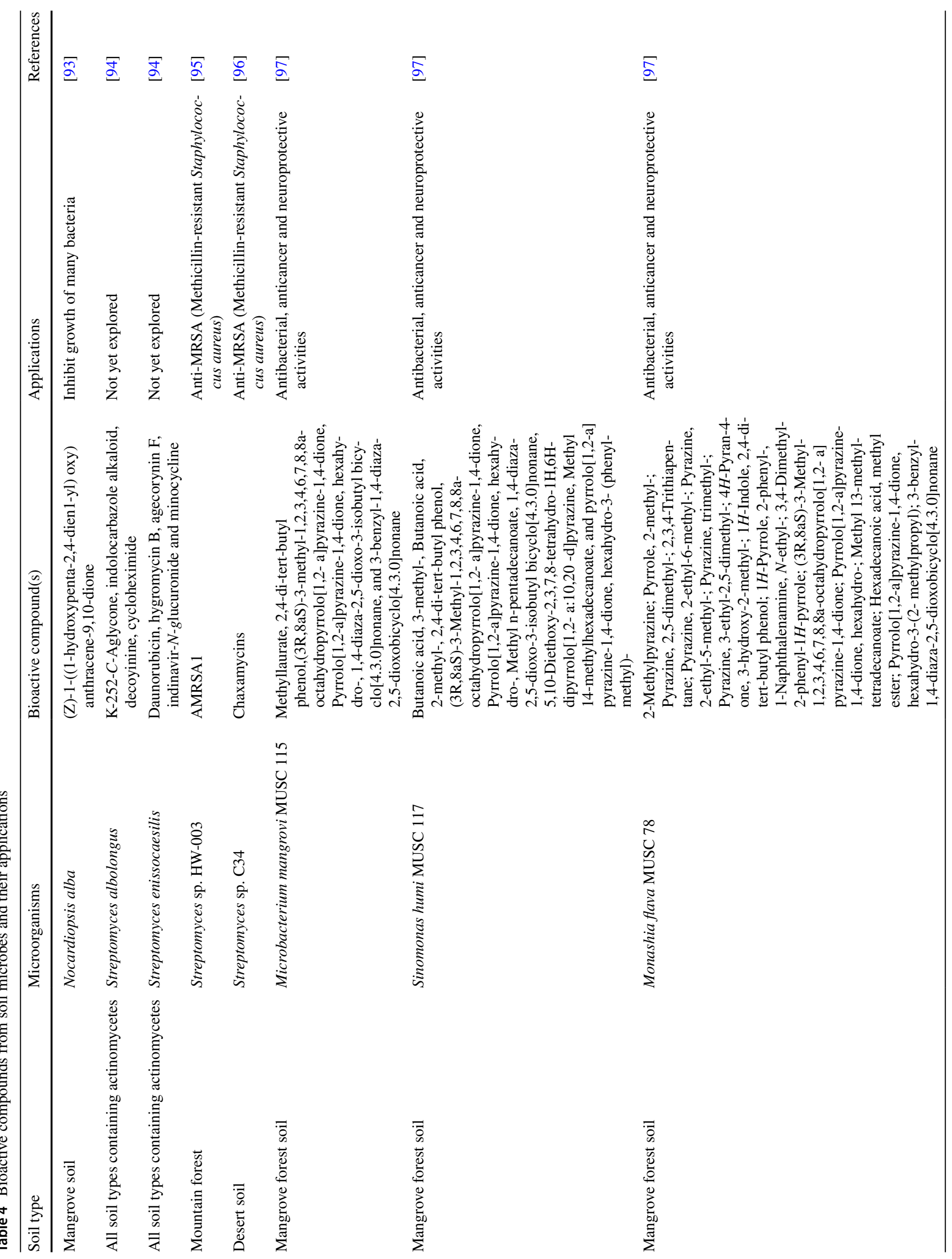




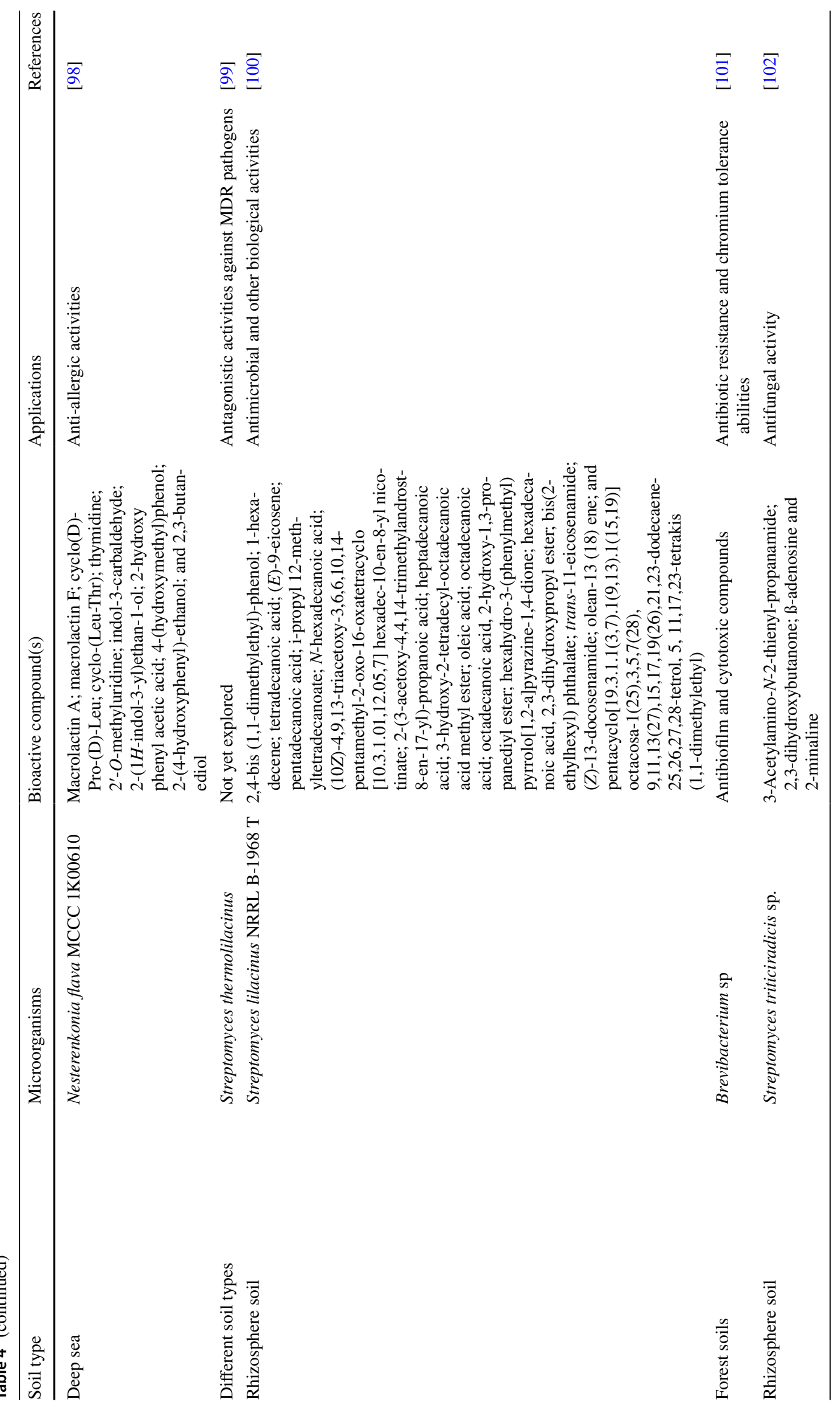


pauroda, proturan, collembolan etc. While microflora and microfauna are those that are less than $0.2 \mathrm{~mm}$ in size.

The physical and biochemical activities taking place in the soil is mostly carried out by the soil microbes. The organism's activity is largely dependent on the size of the organism as well as the diversity of the organisms within the soil habitat [48]. Swift et al. [117] classified soil microbes based on their activities into functional groups as predators, ecosystem engineers, soil-borne pests and diseases, microregulators, decomposers, litter transformers, and prokaryotic transformers. Macrofauna are the major ecosystem engineers, playing a major role in the structural formation of soil. Macrofauna are involved in burrowing activities that provide mechanical mixing and soil disturbances leading to more stable soil aggregates, influencing water and air movement in the soil [118]. Apart from been ecosystem engineers, macrofauna also acts as soil predators and litter decomposers transforming and distributing organic materials in the soil. Mesofauna are majorly involved in the soil activities as predators and decomposers. Their predation activities involve the ingestion of microscopic bacteria, fungi and organic matter, which result in alteration of microbial population, hence affecting the overall performance of the soil ecosystem [119]. They also play a significant role in finely structured soil development [120]. Microfauna and microflora also known as soil microbial biomass, are the tiniest soil organisms playing an active role in microbial processes that enhance soil fertility. They were involved in organic matter transformation, nitrogen fixation, and mineralization of organic nitrogen, phosphorus, sulphur and carbon [121]. Soil microbes have been reported to having wide spectrum of application including crop improvement, remediation of contaminated soils and increased nutrients availability briefly summarized in Table 5 .

Soil microbes play an important role in ensuring food quality [122]. Agricultural practices including medicinal crop production largely depends on chemical inputs. This results in the contamination of soils and the farm produce, which ultimately reduce the efficiency of medicinal plants. With the discoveries of important soil microbes such as free-living and symbiotic microbes that help the plants in different capacities, this menace has been reduced drastically. Now soil microbes are widely used as biofertilizers, biopesticides, bioherbicides and biocontrol agents [122]. This has helped in ensuring the quality of drugs produce in the different soils.

\section{Effect of Soil Particle Size on Soil Microbes}

Weathering of primary minerals occurs over a long period giving rise to soil that contains minerals of different composition and sizes [132]. These differences in the particle size distribution in the soil create a heterogeneous living environment in soil because of the varying levels of nutrients, water contents and oxygen concentrations [121], hence determine activities and types of microorganisms dominated in soil fractions. Assemblages of soil particles during weathering resulted in soils with different pore sizes and shapes. The pore sizes and shapes in the soil determine the amount and configuration of soil water, which in turn determines the diversity and distribution of microorganisms in the soil [133]. Diversity of soil microorganisms increase with a decrease in soil moisture contents [134], this is because, a decrease in soil moisture content results in an increase in a larger number of microhabitats, thereby creating more habitats for microorganisms to colonize [135].

In addition, different stages of weathering produce different soils with different particle sizes. Coarse textured soil compared to fine-textured soil at the same water content and porosity will contain less water filled pores, this will make it have more isolated microhabitat. Therefore, coarse textured soil will have more microbial diversity as more isolated microhabitats will harbour species that might end up competing with each other in the absence of more habitat. Furthermore, a community of soil microbes differs by mineral types and across minerals [136, 137], because most of the soil microbes are adsorbed to soil surfaces than being suspended in soil water. More bacterial community were observed in clay and silt fractions while coarse sand fractions contain higher fungi $[138,139]$. It was also observed that the highest microbial diversity occurred in the $<2 \mu \mathrm{m}$ (sand) particle size fractions [140]. This shows that microbial species richness significantly increased with the coarseness of soil particle sizes [141]. In specific terms, different species of bacteria also have preferences to the surfaces they get adsorbed to base on the soil particle sizes. Hemkemeyer et al. [142] observed that Bacteroides and Alphaproteobacteria prefer to be adsorbed to sand fractions with particulate matter, Gemmatimonadales prefer to be adsorbed to coarse silt, Actinobacteria and Nitrosospira prefer to be adsorbed to fine silt, and Planctomycetales prefer to be adsorbed to clay.

In general terms, apart from the effect of soil particle sizes on soil microbes, topsoil ecosystems consist of more organic materials at a different level of decomposition, these make it to contain more bacteria and fungi. The bacteria and fungi present in the topsoil constitute more than $90 \%$ of the total soil microbial biomass [143], and through their mucilage formation, contributed to the formation of soil aggregates [144]. Therefore, in studying the bioactive compounds produce by soil microbes care must be taking into the type of particle sizes dominated in such soil, as different soil particle produces different population of soil microbes. 

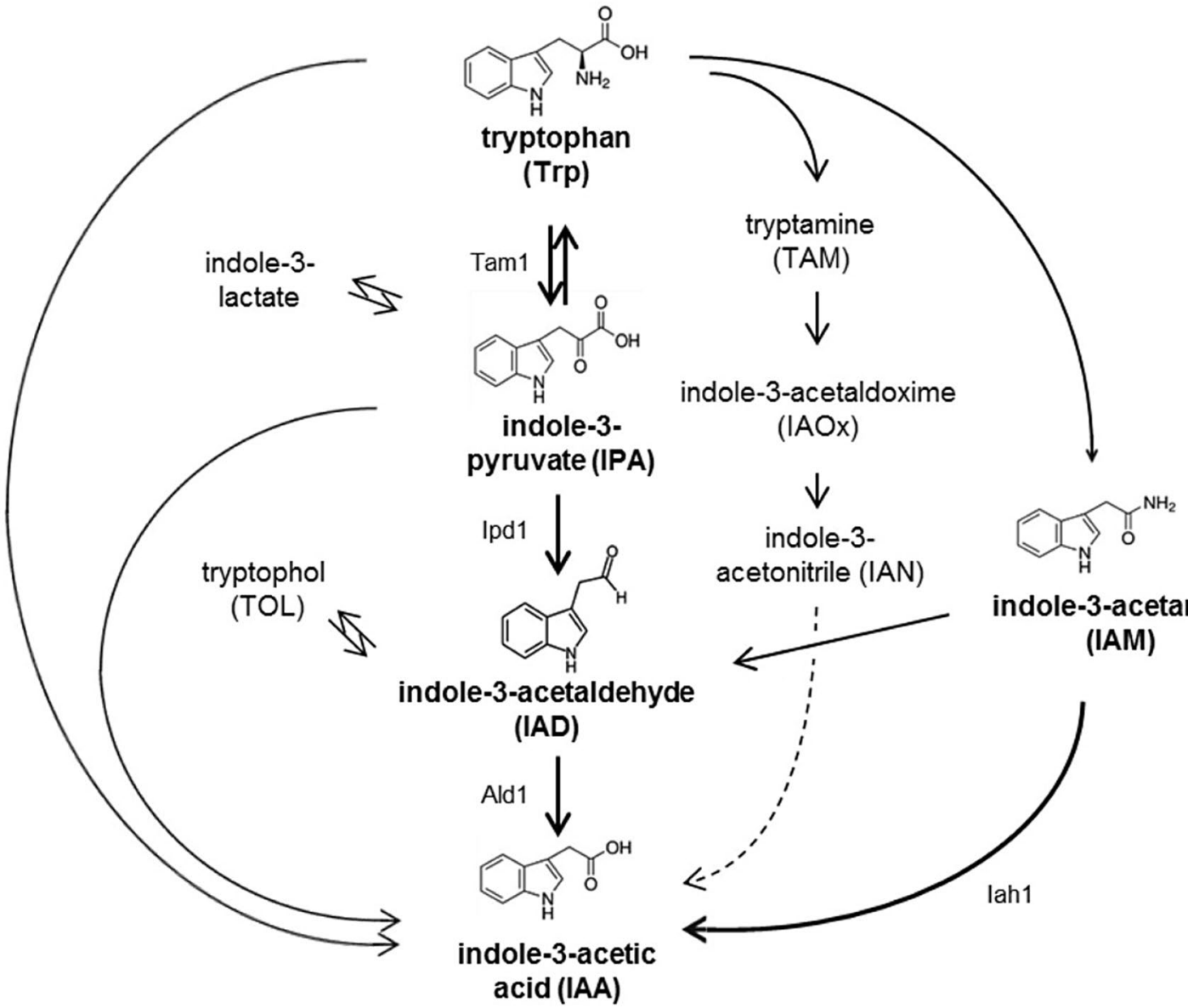

(IAM)

Fig. 3 Biosynthetic pathways of indole-3-acetic acid. Reprinted with permission from Reference [110]

\section{Dispersibility and Stability of Soil Microbes}

The movements, distribution and stability of microorganisms, as well as soil microbes, have been greatly affected by wastewater disposal, tourism and global transport [145]. Before the massive anthropogenic activities that changed our environments today, microorganisms are basically moved by the forces of air and water current. These make them have a biogeographic patterns in the world similar to those of plants and animals [146]. These changes results in substantial alteration in the distribution of microorganisms and has a potential of changing ecosystem services and soil biogeochemistry, which in turn have a significant influence in terms of bioactive compounds obtained from soils and medicinal plants.

More than $359,000 \mathrm{~km}^{2}$ of farmlands were irrigated with wastewater globally, and $80 \%$ of these wastewater undergoes little or no treatments [147]. This gives rise to the introduction of high densities of microorganisms into the croplands, leading to contamination of soil, vegetables, fruits and farm animals. The contaminated materials then served as the dispersal agents that moved different microorganisms to a different part of the world [148]. Unprecedented movements of humans and animals around the world is another factor that leads to the dispersal of microorganisms to a different part of the world. More than 1.2 billion tourists were involved in international tourism per year [149], and millions of animals were involved in longdistance animal migration [150]. These mass movements lead to an increase in both the abundance and distribution of specific gut microorganisms, resulting in the rapid spread of bacterial clones between different continents [151].

Apart from specific gut microorganisms of humans and animals, mass movement of materials and soil destabilization through farming also greatly contribute to the dispersal of microbial cells around the world. Through soil tillage, many soil microbes are exposed to the soil surface which are washed by water or taken away by air to different places. It is estimated that $75 \mathrm{Gt}$ soil is been eroded annually by agriculture compared to $21 \mathrm{Gt}$ eroded by 
Table 5 Soil microbes and their agricultural functions

\begin{tabular}{|c|c|c|c|}
\hline Microbes & Application purposes & Function & References \\
\hline Gluconacetobacter sp & Crop improvement & Increase shoot $\mathrm{Fe}$ and $\mathrm{Zn}$ and shoot dry weight & {$[123]$} \\
\hline Anabaena sp. & Soil improvement & Increase microbial biomass carbon & {$[124]$} \\
\hline Azospirillium brasilense & Crop improvement & Increase shoot $\mathrm{Fe}$ and $\mathrm{Zn}$ and shoot dry weight & {$[123]$} \\
\hline Bacillus sp. & Heavy metals remediation & Removal of $\mathrm{Zn}$ from contaminated soil & {$[125]$} \\
\hline Variovorax paradoxus & Crop improvement & Increase shoot $\mathrm{Fe}$ and $\mathrm{Zn}$ and shoot dry weight & {$[123]$} \\
\hline Fungal community & Crop improvement & Improve growth response of crop & [126] \\
\hline Penicillium bilaiae & Crop improvement & Increase shoot $\mathrm{Fe}$ and $\mathrm{Zn}$ and shoot dry weight & {$[123]$} \\
\hline Rhizobium & Crop improvement & Improve nodulation and nitrogen fixation of crops & {$[127-130]$} \\
\hline Azotobacter sp. & Crop improvement & Increase root weight and yield & [124] \\
\hline Flavobacterium sp. & Nutrient availability & Influence bioavailability of water-soluble $\mathrm{Zn}$ in soil & {$[125]$} \\
\hline Calothrix sp. & Crop improvement & Increase crop $\mathrm{Zn}$ concentration & {$[124]$} \\
\hline Bacterial community & Crop improvement & Improve growth response of crop & [126] \\
\hline Providencia sp. & Soil improvement & Increase microbial biomass carbon & {$[124]$} \\
\hline Pseudomonas aeruginosa & Heavy metals remediation & Removal of $\mathrm{Zn}$ and Se from contaminated soil & {$[125,131]$} \\
\hline
\end{tabular}

natural fluvial erosion [152]. These eroded soil dispersed large number of soil microbes, as the soil can contain billions of microbial cells per gram [145].

The stability of soil microbes is largely affected by two factors i.e. increase microbial communities and soil disturbances [153]. Organic materials application to soil has been proved to raise the level of soil microorganisms' community in the soil $[154,155]$. An increase in soil microbial communities resulted in different types of positive and negative associations, which subsequently resulted in the changes of the soil microbial communities [141, 154, 155]. Soil disturbances, on the other hand, are caused as a result of different farming practices, which result in different degrees of soil disturbances. These make farming practices to effectively change the soil microbial communities [156]. Therefore, these two factors result in the increase or decrease of soil microbes, hence destabilizing the communities of the soil microbes. Hence, for efficient utilization of soil microbes as good sources of bioactive compounds, the aforementioned factors most be given satisfactory attention so as to preserve the sources of the bioactive compounds presents for medicinal purposes.

\section{Future Outlook}

The discovery of new drugs through isolation from medicinal plants, including the ability to determine and improve the quality of bioactive compounds from the microbial sources, should remain an active field of research in the modern scientific world. With the rapid spread of diseases such as novel coronavirus (COVID-19) with no known cure yet, the opportunity to discover new compounds from plants and microbial sources, including a new group of compounds to combat diseases, is therefore necessary. In most, if not all cases, new drugs are designed with potency against various ailments. The hope of the world would in the future rely on the understanding of the role of active compounds and the discovery of new specialized metabolites. The quantitative study, molecular docking, and dynamic simulation studies should be performed on the already known active compounds and the optimization of these compounds would be a scientifically rewarding activity. The theoretical investigations should take lead in determining the interaction of active compounds with microorganisms to produce drugs with better activity. Also, there is an increasing interest in the studies of the rates and mechanisms of individual factors combined with new techniques of achieving optimum product quality of new drugs derived from plants. The development and application of computational designs and models in predicting the behavior of these bioactive constituents is given a lead to a groundbreaking research. Optimization of the various active compounds for maximum product quality is also necessary through which continued advancement in science can be achieved. Also, the ability to provide immediate access to the enzymes involved in the biosynthesis of specialized metabolites will give newer opportunities to develop better derivatives of bioactive compounds. Again, the strategies to be used for improving the role of bioactive compounds in curing diseases will in the future lies with the application of NPs for the benefits of man and plants against microbial pathogens. We hope soon, the various pollutants in the soil if well treated will provide abundant products of novel bioactive compounds from both plant and microbial sources. Finally, people should be educated on the dangers of polluting active products of medicinal plants as well as that of soil microbes, and the overall effects it has on our world. Despite the modernization and urbanization of 
countries in the twenty-first century, the government and the relevant authorities should encourage the people to practice safe disposal of refuse, replantation of medicinal plants not just in the remote areas but even in the urban centers.

\section{Compliance with Ethical Standards}

Conflict of interest The authors declare that they have no competing interests.

\section{References}

1. Cragg GM, Newman DJ (2013) Natural products: a continuing source of novel drug leads. Biochim Biophys Acta Gen Subj 180(6):3670-3695. https://doi.org/10.1016/j.bbagen.2013.02.008

2. David B, Wolfender JL, Dias DA (2015) The pharmaceutical industry and natural products: historical status and new trends. Phytochem Rev 14(2):299-315. https://doi.org/10.1007/s1110 1-014-9367-z

3. Ribeiro DA, Damasceno SS, Boligon AA, de Menezes IRA, Souza MMdA, da Costa JGM (2017) Chemical profile and antimicrobial activity of Secondatia floribunda A. DC (Apocynaceae). Asian Pac J Trop Biomed 7(8):739-749. https://doi. org/10.1016/j.apjtb.2017.07.009

4. Dias DA, Urban S, Roessner U (2012) A Historical overview of natural products in drug discovery. Metabolites 2(2):303-336. https://doi.org/10.3390/metabo2020303

5. Savoia D (2012) Plant-derived antimicrobial compounds: alternatives to antibiotics. Future Microbiol 7(8):979-990. https://doi. org/10.2217/fmb.12.68

6. Monciardini P, Iorio M, Maffioli S, Sosio M, Donadio S (2014) Minireview: Discovering new bioactive molecules from microbial sources. Microb Biotechnol. https://doi. org/10.1111/1751-7915.12123

7. Gao Y, Zhou P, Mao L, Ye Z, Wj S (2010) Assessment of effects of heavy metals combined pollution on soil enzyme activities and microbial community structure: modified ecological doseresponse model and PCR-RAPD. Environ Earth Sci 60(3):603612. https://doi.org/10.1007/s12665-009-0200-8

8. Llinson GRA, Menzies NWM (2010) Inter-regional variability in environmental availability of fungicide derived copper in vineyard soils: an australian case study. 449-457. https://doi. org/10.1021/jf9030647

9. Mackie KA, Müller T, Zikeli S, Kandeler E (2013) Long-term copper application in an organic vineyard modifies spatial distribution of soil micro-organisms. Soil Biol Biochem 65:245-253. https://doi.org/10.1016/j.soilbio.2013.06.003

10. Onojake MC, Frank O (2013) Assessment of heavy metals in a soil contaminated by oil spill: a case study in Nigeria. Chem Ecol 29(3):246-254. https://doi.org/10.1080/02757540.2012.717619

11. Bloem J, De Ruiter P, Bouwman L (1997) Soil food webs and nutrient cycling in agroecosystems. Modern soil microbiology. Marcel Dekker, New York, pp 245-278

12. Schulten HR, Leinweber P (1999) Thermal stability and composition of mineral-bound organic matter in density fractions of soil. Eur J Soil Sci 50(2):237-248. https://doi.org/10.104 6/j.1365-2389.1999.00241.x

13. Arias ME, González-pérez JA, González-vila FJ, Ball AS (2005) Soil health - a new challenge for microbiologists and chemists. Int Microbiol 13-21
14. Larue C, Castillo-Michel H, Sobanska S, Cécillon L, Bureau S, Barthès V, Ouerdane L, Carrière M, Sarret G (2014) Foliar exposure of the crop Lactuca sativa to silver nanoparticles: evidence for internalization and changes in Ag speciation. J Hazard Mater 264:98-106. https://doi.org/10.1016/j.jhazmat.2013.10.053

15. Suppan S (2013) Nanomaterials in soil: our future food chain?. Institute for Agriculture and Trade Policy, Minneapolis. www. iatp.org

16. Ge Y, Schimel JP, Holden PA (2011) Evidence for negative effects of $\mathrm{TiO}_{2}$ and $\mathrm{ZnO}$ nanoparticles on soil bacterial communities. Environ Sci Technol 45(4):1659-1664. https://doi. org/10.1021/es103040t

17. Rousk J, Ackermann K, Curling SF, Jones DL (2012) Comparative toxicity of nanoparticulate $\mathrm{CuO}$ and $\mathrm{ZnO}$ to soil bacterial communities. PLoS ONE. https://doi.org/10.1371/journ al.pone.0034197

18. Xu C, Peng C, Sun L, Zhang S, Huang H, Chen Y, Shi J (2015) Distinctive effects of $\mathrm{TiO} 2$ and $\mathrm{CuO}$ nanoparticles on soil microbes and their community structures in flooded paddy soil. Soil Biol Biochem 86:24-33

19. Esquenazi E, Yang YL, Watrous J, Gerwick WH, Dorrestein PC (2009) Imaging mass spectrometry of natural products. Nat Prod Rep 26(12):1521-1534. https://doi.org/10.1039/b915674g

20. Ai C, Li Y, Wang Y, Chen Y, Yang L (2009) Insight into the effects of chiral isomers quinidine and quinine on CYP2D6 inhibition. Bioorg Med Chem Lett 19(3):803-806. https://doi. org/10.1016/j.bmcl.2008.12.016

21. Ma Z, Lee I, Zaera F (2007) Factors controlling adsorption equilibria from solution onto solid surfaces: the uptake of cinchona alkaloids on platinum surfaces. J Am Chem Soc 129(51):1608316090. https://doi.org/10.1021/ja076011a

22. Altemimi A, Lakhssassi N, Baharlouei A, Watson DG, Lightfoot DA (2017) Phytochemicals: extraction, isolation, and identification of bioactive compounds from plant extracts. Plants. https:// doi.org/10.3390/plants6040042

23. Al-Bayati FA, Al-Mola HF (2008) Antibacterial and antifungal activities of different parts of Tribulus terrestris L. growing in Iraq. J Zhejiang Univ Sci B 9(2):154-159

24. Sondi I, Salopek-Sondi B (2004) Silver nanoparticles as antimicrobial agent: a case study on E. coli as a model for Gramnegative bacteria. J Colloid Interface Sci 275(1):177-182

25. Naz R, Bano A (2013) Phytochemical screening, antioxidants and antimicrobial potential of Lantana camara in different solvents. Asian Pac J Trop Dis 3(6):480-486. https://doi.org/10.1016/ S2222-1808(13)60104-8

26. Albayrak S, Aksoy A, Albayrak S, Sagdic O (2013) In vitro antioxidant and antimicrobial activity of some Lamiaceae species. Iran J Sci Technol A 37:1-9

27. Mandal S, Debmandal M, Saha K, Pal NK (2011) In vitro antibacterial activity of three indian spices against methicillin. Resistant. 26(5):319-323

28. Aja PM, Okaka ANC, Onu PN, Ibiam U, Urako AJ (2010) Phytochemical composition of Talinum triangulare (water leaf) leaves. Pak J Nutr 9(6):527-530. https://doi.org/10.3923/ pjn.2010.527.530

29. Aliyu AB, Musa AM, Abdullahi MS, Ibrahim H, Oyewale AO (2011) Phytochemical screening and antibacterial activities of Vernonia ambigua, Vernonia blumeoides and Vernonia oocephala (asteraceae). Acta Poloniae Pharmaceutica Drug Res 68(1):67-73

30. Musa A, Abbas G, Aliyu A, Abdullahi M, Akpulu I (2008) Phytochemical and antimicrobial screening of Indigofera conferta Gillett (Papilionaceae). Res J Med Plant 2(2):74-78

31. Obiang C, Ngoua Meye Misso R, Ndong Atome G, Ondo J, Obame Engonga L, Emvo E (2019) Phytochemical analyses, antimicrobial and antioxidant activities of stem bark extracts 
of Distemonanthus benthamianus H. Baill and fruit extracts of Solanum torvum Sw. from Gabon. Asian Pac J Trop Biomed 9(5):209-216. https://doi.org/10.4103/2221-1691.259001

32. Ngoua-Meye-Misso R-L, Sima-Obiang C, Ndong JDLC, Ondo JP, Ovono Abessolo F, Obame-Engonga L-C (2018) Phytochemical screening, antioxidant, anti-inflammatory and antiangiogenic activities of Lophira procera A. Chev (Ochnaceae) medicinal plant from Gabon. Egypt J Basic Appl Sci 5(1):8086. https://doi.org/10.1016/j.ejbas.2017.11.003

33. Takaidza S, Mtunzi F, Pillay M (2018) Analysis of the phytochemical contents and antioxidant activities of crude extracts from Tulbaghia species. J Tradit Chin Med 38(2):272-279. https://doi.org/10.1016/j.jtcm.2018.04.005

34. Obiang CS, Ondo JP, Atome GRN, Engonga LCO, Siawaya JFD, Emvo EN (2016) Phytochemical screening, antioxidant and antimicrobial potential of stem barks of Coula edulis Baill. Pseudospondias longifolia Engl and Carapa klaineana Pierre from Gabon. Asian Pac J Trop Dis 6(7):557-563. https://doi. org/10.1016/S2222-1808(16)61086-1

35. Eswaraiah G, Peele KA, Krupanidhi S, Kumar RB, Venkateswarulu TC (2020) Studies on phytochemical, antioxidant, antimicrobial analysis and separation of bioactive leads of leaf extract from the selected mangroves. J King Saud Univ Sci 32(1):842-847. https://doi.org/10.1016/j.jksus.2019.03.002

36. Musa A, Ibrahim M, Aliyu A, Abdullahi M, Tajuddeen N, Ibrahim H, Oyewale A (2015) Chemical composition and antimicrobial activity of hexane leaf extract of Anisopus mannii (Asclepiadaceae). J Intercult Ethnopharmacol 4(2):129-129. https://doi.org/10.5455/jice.20150106124652

37. Wang J, Shu K, Zhang L, Si Y (2017) Effects of silver nanoparticles on soil microbial communities and bacterial nitrification in suburban vegetable soils. Pedosphere 27(3):482-490. https ://doi.org/10.1016/S1002-0160(17)60344-8

38. Sillen WMA, Thijs S, Abbamondi GR, Janssen J, Weyens N, White JC, Vangronsveld J (2015) Effects of silver nanoparticles on soil microorganisms and maize biomass are linked in the rhizosphere. Soil Biol Biochem 91(August):14-22. https://doi. org/10.1016/j.soilbio.2015.08.019

39. Durenkamp M, Pawlett M, Ritz K, Harris JA, Neal AL, McGrath SP (2016) Nanoparticles within WWTP sludges have minimal impact on leachate quality and soil microbial community structure and function. Environ Pollut 211:399-405. https://doi.org/10.1016/j.envpol.2015.12.063

40. Samarajeewa AD, Velicogna JR, Princz JI, Subasinghe RM, Scroggins RP, Beaudette LA (2017) Effect of silver nano-particles on soil microbial growth, activity and community diversity in a sandy loam soil. Environ Pollut 220:504-513. https://doi. org/10.1016/j.envpol.2016.09.094

41. Kaye JP, McCulley RL, Burke IC (2005) Carbon fluxes, nitrogen cycling, and soil microbial communities in adjacent urban, native and agricultural ecosystems. Glob Change Biol 11(4):575-587. https://doi.org/10.111 1/j.1365-2486.2005.00921.x

42. Colman BP, Arnaout CL, Anciaux S, Gunsch CK, Hochella MF, Kim B, Lowry GV, McGill BM, Reinsch BC, Richardson CJ, Unrine JM, Wright JP, Yin L, Bernhardt ES (2013) Low concentrations of silver nanoparticles in biosolids cause adverse ecosystem responses under realistic field scenario. PLoS ONE. https://doi.org/10.1371/journal.pone.0057189

43. Gitipour A, Thiel SW, Scheckel KG, Tolaymat T (2016) Anaerobic toxicity of cationic silver nanoparticles. Sci Total Environ 557-558:363-368. https://doi.org/10.1016/j.scito tenv.2016.02.190

44. He S, Feng Y, Ni J, Sun Y, Xue L, Feng Y, Yu Y, Lin X, Yang L (2016) Different responses of soil microbial metabolic activity to silver and iron oxide nanoparticles. Chemosphere 147:195-202. https://doi.org/10.1016/j.chemosphere.2015.12.055

45. Bao S, Wang H, Zhang W, Xie Z, Fang T (2016) An investigation into the effects of silver nanoparticles on natural microbial communities in two freshwater sediments. Environ Pollut 219:696-704. https://doi.org/10.1016/j.envpol.2016.06.071

46. Yang Y, Quensen J, Mathieu J, Wang Q, Wang J, Li M, Tiedje JM, Alvarez PJJ (2014) Pyrosequencing reveals higher impact of silver nanoparticles than $\mathrm{Ag}+$ on the microbial community structure of activated sludge. Water Res 48(1):317-325. https:// doi.org/10.1016/j.watres.2013.09.046

47. Lajayer BA, Ghorbanpour M, Nikabadi S (2017) Heavy metals in contaminated environment: destiny of secondary metabolite biosynthesis, oxidative status and phytoextraction in medicinal plants. Ecotoxicol Environ Saf 145:377-390

48. Abdu N, Abdullahi AA, Abdulkadir A (2017) Heavy metals and soil microbes. Environ Chem Lett 15(1):65-84

49. Kabata-Pendias A (2001) Trace metals in soils-a current issue in Poland. Acta Universitatis Wratislaviensis Prace Botaniczne 79:13-20

50. Bach EM, Baer SG, Meyer CK, Six J (2010) Soil texture affects soil microbial and structural recovery during grassland restoration. Soil Biol Biochem 42(12):2182-2191. https://doi. org/10.1016/j.soilbio.2010.08.014

51. Rajaniemi TK, Allison VJ (2009) Abiotic conditions and plant cover differentially affect microbial biomass and community composition on dune gradients. Soil Biol Biochem 41(1):102109. https://doi.org/10.1016/j.soilbio.2008.10.001

52. Marslin G, Siram K, Maqbool Q, Selvakesavan RK, Kruszka D, Kachlicki P, Franklin G (2018) Secondary metabolites in the green synthesis of metallic nanoparticles. Materials 11(6):1-25. https://doi.org/10.3390/ma11060940

53. Khamna S, Yokota A, Peberdy JF, Lumyong S (2010) Indole3 -acetic acid production by Streptomyces $\mathrm{sp}$. isolated from some Thai medicinal plant rhizosphere soils. Eur Asian J Biosci 32:2332. https://doi.org/10.5053/ejobios.2010.4.0.4

54. Ye S, Zeng G, Wu H, Zhang C, Liang J, Dai J (2017) Cooccurrence and interactions of pollutants, and their impacts on soil remediation-A review. 3389 (October). https://doi. org/10.1080/10643389.2017.1386951

55. Mehmood T, Malik SA, Hussain ST (2009) Role of microbes in nitrogen and metal hyperaccumulation by taxilaion Eichhornia crassipes. Afr J Microbiol Res 3(12):914-924

56. Yazdani D (2011) A review on bioactive compounds isolated from plants against plant pathogenic fungi. J Med Plants Res 5(30):6584-6589. https://doi.org/10.5897/jmpr11.485

57. Shoemaker M, Hamilton B, Dairkee SH, Cohen I, Campbell MJ (2005) In vitro anticancer activity of twelve Chinese medicinal herbs. Phytother Res 19(7):649-651. https://doi.org/10.1002/ ptr.1702

58. Mustafa G, Arif R, Atta A, Sharif S, Jamil A (2017) Bioactive compounds from medicinal plants and their importance in drug discovery in Pakistan. Matrix Sci Pharma 1(1):17-26. https://doi. org/10.26480/msp.01.2017.17.26

59. Pezzuto JM (1997) Plant-derived anticancer agents. Biochem Pharmacol 53(2):121-133. https://doi.org/10.1016/S0006 -2952(96)00654-5

60. Shahid M, Shahzad A, Tripathi T, Sobia F, Sahai F, Singh A, Malik A, Shujatullah F, Khan HM (2009) Recent trends in plant-derived antifungal agents. Anti Infect Agents Med Chem 8(1):36-49. https://doi.org/10.2174/187152109787047788

61. Shiu WKP, Malkinson JP, Rahman MM, Curry J, Stapleton P, Gunaratnam M, Neidle S, Mushtaq S, Warner M, Livermore DM, Evangelopoulos D, Basavannacharya C, Bhakta S, Schindler BD, Seo SM, Coleman D, Kaatz GW, Gibbons S (2013) A new plant-derived antibacterial is an inhibitor of efflux pumps 
in Staphylococcus aureus. Int J Antimicrob Agents 42(6):513518. https://doi.org/10.1016/j.ijantimicag.2013.08.007

62. De Lucca AJ, Walsh TJ (1999) Antifungal peptides: novel therapeutic compounds against emerging pathogens. Antimicrob Agents Chemother 43(1):1-11. https://doi.org/10.1128/ aac.43.1.1

63. Wink M (2012) Medicinal plants: a source of anti-parasitic secondary metabolites. Molecules 17(11):12771-12791. https ://doi.org/10.3390/molecules171112771

64. Fatma G, Sami BHA, Ahmed L (2017) Investigation of extracts from Tunisian ethnomedicinal plants as antioxidants, cytotoxins, and antimicrobials. Biomed Environ Sci 30(11):811-824

65. Mostafa AA, Al-Askar AA, Almaary KS, Dawoud TM, Sholkamy EN, Bakri MM (2018) Antimicrobial activity of some plant extracts against bacterial strains causing food poisoning diseases. Saudi J Biol Sci 25(2):361-366

66. Rakholiya K, Kaneria M, Chanda S (2014) Inhibition of microbial pathogens using fruit and vegetable peel extracts. Int $\mathbf{J}$ Food Sci Nutr 65(6):733-739

67. Mishra MP, Rath S, Swain SS, Ghosh G, Das D, Padhy RN (2017) In vitro antibacterial activity of crude extracts of 9 selected medicinal plants against UTI causing MDR bacteria. J King Saud Univ Sci 29(1):84-95

68. Sharma V (2013) Part based HPLC-PDA quantification of podophyllotoxin in populations of Podophyllum hexandrum Royle "Indian Mayapple" from higher altitude Himalayas. J Med Plants Stud 1(3):176-183

69. Jena J, Gupta AK (2012) Ricinus communis Linn: a phytopharmacological review. International Journal of Pharmacy and Pharmaceutical Sciences 4(4):25-29

70. Bag A, Bhattacharyya SK, Chattopadhyay RR (2013) The development of Terminalia chebula Retz. (Combretaceae) in clinical research. Asian Pac J Trop Biomed 3(3):244-252

71. Das SK, Mukherjee S, Vasudevan D (2008) Medicinal properties of milk thistle with special reference to silymarin-an overview. Nat Prod Radiance 7:182-192

72. Oyemitan IA, Elusiyan CA, Akinkunmi EO, Obuotor EM, Akanmu MA, Olugbade TA (2019) Memory enhancing, anticholinesterase and antimicrobial activities of $\beta$-phenylnitroethane and essential oil of Dennettia tripetala Baker f. J Ethnopharmacol 229:256-261

73. Paarakh PM (2010) Terminalia arjuna (Roxb) Wt and Arn: a review. IJP-Int J Pharmacol 6(5):515-534

74. Gaire BP, Subedi L (2014) Phytochemistry, pharmacology and medicinal properties of Phyllanthus emblica Linn. Chin J Integr Med 1-8

75. Titanji VP, Zofou D, Ngemenya MN (2008) The antimalarial potential of medicinal plants used for the treatment of malaria in Cameroonian folk medicine. Afr J Tradit Complement Altern Med 5(3):302

76. Mittal J, Sharma MM, Batra A (2014) Tinospora cordifolia: a multipurpose medicinal plant-A. J Med Plants Stud 2:32-47

77. Hajji M, Hamdi M, Sellimi S, Ksouda G, Laouer H, Li S, Nasri M (2019) Structural characterization, antioxidant and antibacterial activities of a novel polysaccharide from Periploca laevigata root barks. Carbohyd Polym 206:380-388

78. Farjana A, Zerin N, Kabir MS (2014) Antimicrobial activity of medicinal plant leaf extracts against pathogenic bacteria. Asian Pac J Trop Dis 4:S920-S923

79. Ved A, Arsi T, Prakash O, Gupta A (2018) A review on phytochemistry and pharmacological activity of Lantana camara Linn. Int J Pharm Sci Res 9(1):37-43

80. Yesmin MN, Uddin SN, Mubassara S, Akond MA (2008) Antioxidant and antibacterial activities of Calotropis procera Linn. Am-Eur J Agric Environ Sci 4(5):550-553
81. Iqbal Z, Lateef M, Jabbar A, Muhammad G, Khan MN (2005) Anthelmintic activity of Calotropis procera (Ait.) Ait F. flowers in sheep. J Ethnopharmacol 102(2):256-261

82. Muhammad AA, Pauzi NAS, Arulselvan P, Abas F, Fakurazi S (2013) In vitro wound healing potential and identification of bioactive compounds from Moringa oleifera Lam. BioMed Res Int. https://doi.org/10.1155/2013/974580

83. Farooq F, Rai M, Tiwari A, Khan AA, Farooq S (2012) Medicinal properties of Moringa oleifera: an overview of promising healer. J Med Plants Res 6(27):4368-4374

84. Boakye-Gyasi E, Henneh IT, Abotsi WKM, Ameyaw EO, Woode E (2017) Hydro-ethanolic leaf extract of Ziziphus abyssinica Hochst Ex A Rich (Rhamnaceae) exhibits anti-nociceptive effects in murine models. BMC Complement Altern Med 17(1):1-12

85. Nyaberi M, Onyango C, Mathooko F, Maina J, Makobe M, Mwaura F (2010) Evaluation of phytochemical, antioxidant and antibacterial activity of edible fruit extracts of Ziziphus abyssinica A. Rich for meat preservation. J Anim Plant Sci 6(2):623-629

86. Fiot J, Sanon S, Azas N, Mahiou V, Jansen O, Angenot L, Balansard G, Ollivier E (2006) Phytochemical and pharmacological study of roots and leaves of Guiera senegalensis JF Gmel (Combretaceae). J Ethnopharmacol 106(2):173-178

87. Batiha GE-S, Alkazmi LM, Wasef LG, Beshbishy AM, Nadwa EH, Rashwan EK (2020) Syzygium aromaticum L. (Myrtaceae): traditional uses, bioactive chemical constituents, pharmacological and toxicological activities. Biomolecules 10(2):202

88. Islam NU, Amin R, Shahid M, Amin M, Zaib S, Iqbal J (2017) A multi-target therapeutic potential of Prunus domestica gum stabilized nanoparticles exhibited prospective anticancer, antibacterial, urease-inhibition, anti-inflammatory and analgesic properties. BMC Complement Altern Med 17(1):276

89. Donadio S, Monciardini P, Alduina R, Mazza P, Chiocchini C, Ca L, Sosio M, Maria A (2002) Microbial technologies for the discovery of novel bioactive metabolites. 99 (v)

90. Davies J, Ryan KS (2012) Introducing the parvome: bioactive compounds in the microbial world. ACS Chem Biol 7(2):252259. https://doi.org/10.1021/cb200337h

91. Brown T (2008) Deisign thinking. Harvard Bus Rev 86(6):84-92. https://doi.org/10.1002/med

92. Ahsan T, Chen J, Zhao X, Irfan M, Wu Y (2017) Extraction and identification of bioactive compounds (eicosane and dibutyl phthalate) produced by Streptomyces strain KX852460 for the biological control of Rhizoctonia solani AG-3 strain KX852461 to control target spot disease in tobacco leaf. AMB Express. https ://doi.org/10.1186/s13568-017-0351-z

93. Janardhan A, Kumar AP, Viswanath B, Saigopal D, Narasimha G (2014) Production of bioactive compounds by actinomycetes and their antioxidant properties. Biotechnology Res Int 55:1897-1901

94. Kumar P, Kundu A, Kumar M, Solanki R, Kapur MK (2019) Exploitation of potential bioactive compounds from two soil derived actinomycetes, Streptomyces sp strain 196 and RI24. Microbiol Res 229:126312. https://doi.org/10.1016/j.micre s.2019.126312

95. Kemung HM, Tan LT-H, Khan TM, Chan K-G, Pusparajah P, Goh B-H, Lee L-H (2018) Streptomyces as a prominent resource of future anti-MRSA drugs. Front Microbiol 9:2221

96. Rateb ME, Houssen WE, Arnold M, Abdelrahman MH, Deng H, Harrison WT, Okoro CK, Asenjo JA, Andrews BA, Ferguson G (2011) Chaxamycins A-D, bioactive ansamycins from a hyperarid desert Streptomyces sp. J Nat Prod 74(6):1491-1499

97. Azman A-S, Othman I, Fang C-M, Chan K-G, Goh B-H, Lee L-H (2017) Antibacterial, anticancer and neuroprotective activities of rare Actinobacteria from mangrove forest soils. Indian $\mathbf{J}$ Microbiol 57(2):177-187 
98. Xie C-L, Liu Q, Xia J-M, Gao Y, Yang Q, Shao Z-Z, Liu G, Yang X-W (2017) Anti-allergic compounds from the deep-seaderived actinomycete Nesterenkonia flava MCCC 1K00610. Marine drugs 15(3):71

99. Talpur M-KA, Qazi MA, Phulpoto AH, Maitlo MA, Phulpoto IA, Syed FH, Wassan SA, Saand MA, Kanhar NA (2020) Bioprospecting actinobacterial diversity antagonistic to multidrugresistant bacteria from untapped soil resources of Kotdiji Pakistan. Biologia 75(1):129-138

100. Qi D, Zou L, Zhou D, Chen Y, Gao Z, Feng R, Zhang M, Li K, Xie J, Wang W (2019) Taxonomy and broad-spectrum antifungal activity of Streptomyces sp. SCA3-4 isolated from rhizosphere soil of opuntia stricta. Front Microbiol 10:1390. https://doi. org/10.3389/fmicb.2019.01390

101. Soyer P, Tunalı Y (2020) Actinobacteria isolation from forest soils and determination of biological activities. J. Turk Chem Soc Sect A: Chem. https://doi.org/10.18596/jotcsa.657180

102. Yu Z, Han C, Yu B, Zhao J, Yan Y, Huang S, Liu C, Xiang W (2020) Taxonomic characterization, and secondary metabolite analysis of Streptomyces triticiradicis sp nov: a novel actinomycete with antifungal activity. Microorganisms 8(1):77. https:// doi.org/10.3390/microorganisms 8010077

103. Singh M, Kumar A, Singh R, Pandey KD (2017) Endophytic bacteria: a new source of bioactive compounds. 3Biotech. https ://doi.org/10.1007/s13205-017-0942-Z

104. Xue L, Xue Q, Chen Q, Lin C, Shen G, Zhao J (2013) Isolation and evaluation of rhizosphere actinomycetes with potential application for biocontrol of Verticillium wilt of cotton. Crop Protect 43:231-240. https://doi.org/10.1016/j.cropro.2012.10.002

105. Zeng Q, Huang H, Zhu J, Fang Z, Sun Q, Bao S (2013) A new nematicidal compound produced by Streptomyces albogriseolus HA10002. Antonie Van Leeuwenhoek 103(5):1107-1111. https ://doi.org/10.1007/s10482-013-9890-8

106. Islam F, Yasmeen T, Arif MS, Ali S, Ali B, Hameed S, Zhou W (2016) Plant growth promoting bacteria confer salt tolerance in Vigna radiata by up-regulating antioxidant defense and biological soil fertility. Plant Growth Regul 80(1):23-36. https://doi. org/10.1007/s10725-015-0142-y

107. Liu Y, Guo J, Li L, Asem MD, Zhang Y, Mohamad OA, Salam N, Li W (2017) Endophytic bacteria associated with endangered plant Ferula sinkiangensis KM Shen in an arid land: diversity and plant growth-promoting traits. Journal of Arid Land 9(3):432445. https://doi.org/10.1007/s40333-017-0015-5

108. Liu Y-H, Guo J-W, Salam N, Li L, Zhang Y-G, Han J, Mohamad OA, Li W-J (2016) Culturable endophytic bacteria associated with medicinal plant Ferula songorica: molecular phylogeny, distribution and screening for industrially important traits. 3Biotech 6(2):209. https://doi.org/10.1007/s13205-016-0522-7

109. Duca D, Lorv J, Patten CL, Rose D, Glick BR (2014) Indole3 -acetic acid in plant-microbe interactions. Antonie Van Leeuwenhoek 106(1):85-125. https://doi.org/10.1007/s1048 2-013-0095-y

110. Bartel B (1997) Auxin biosynthesis. Annu Rev Plant Biol 48(1):51-66. https://doi.org/10.1146/annurev.arplant.48.1.51

111. Finn PW, Kavraki LE (1999) Computational approaches to drug design. Algorithmica (New York) 25(2-3):347-371. https://doi. org/10.1007/PL00008282

112. Tan JJ, Cong XJ, Hu LM, Wang CX, Jia L, Liang XJ (2010) Therapeutic strategies underpinning the development of novel techniques for the treatment of HIV infection. Drug Discov Today 15(5-6):186-197. https://doi.org/10.1016/j.drudis.2010.01.004

113. Adeniji SE, Shallangwa GA, Arthur DE, Abdullahi M, Mahmoud AY, Haruna A (2020) Heliyon Quantum modelling and molecular docking evaluation of some selected quinoline derivatives as anti-tubercular agents. Heliyon 6(January):e03639-e03639. https ://doi.org/10.1016/j.heliyon.2020.e03639
114. Elijah S, David A, Arthur E, Abdullahi M, Haruna A (2020) Quantitative structure activity relationship model, molecular docking simulation and computational design of some novel compounds against DNA gyrase receptor. Chem Afr. https://doi. org/10.1007/s42250-020-00132-9

115. Abdulfatai U, Uzairu A, Shallangwa GA, Uba S (2020) Designing and estimating antioxidant properties of some lubricant additives via QSPR and MD methodologies. Sci Afr 8:e00451. https ://doi.org/10.1016/j.sciaf.2020.e00451

116. Portillo MC, Leff JW, Lauber CL, Fierer N (2013) Cell size distributions of soil bacterial and archaeal taxa. Appl Environ Microbiol 79(24):7610-7617

117. Swift M, Bignell DE, Moreira FMdS, Huising J (2008) The inventory of soil biological diversity: concepts and general guidelines. In: A handbook of tropical soil biology: sampling and characterization of below-ground biodiversity. Earthscan Publishers, New York

118. Ayuke FO (2010) Soil macrofauna functional groups and their effects on soil structure, as related to agricultural management practices across agroecological zones of Sub-Saharan Africa. $\mathrm{PhD}$ thesis, Wageningen University, The Netherlands, pp. 41-64

119. Schloter M, Nannipieri P, Sørensen SJ, van Elsas JD (2018) Microbial indicators for soil quality. Biol Fertil Soils 54(1):1-10

120. Emmerling C, Schloter M, Hartmann A, Kandeler E (2002) Functional diversity of soil organisms - a review of recent research activities in Germany. J Plant Nutr Soil Sci 165(4):408-420

121. Nannipieri P, Ascher J, Ceccherini M, Landi L, Pietramellara G, Renella G (2017) Microbial diversity and soil functions. Eur J Soil Sci 68(1):12-26

122. Alori ET, Babalola OO (2018) Microbial inoculants for improving crop quality and human health in Africa. Front Microbiol 9:2213

123. Fei H, Crouse M, Papdopoulos YA, Vessey JK (2019) Improving biomass yield of giant Miscanthus by application of beneficial soil microbes and a plant biostimulant. Can J Plant Sci. https:// doi.org/10.1139/cjps-2019-0012

124. Manjunath M, Kanchan A, Ranjan K, Venkatachalam S, Prasanna R, Ramakrishnan B, Hossain F, Nain L, Shivay YS, Rai AB (2016) Beneficial cyanobacteria and eubacteria synergistically enhance bioavailability of soil nutrients and yield of okra. Heliyon 2(2): 000066

125. He CQ, Tan G, Liang X, Du W, Chen Y, Zhi G, Zhu Y (2010) Effect of Zn-tolerant bacterial strains on growth and $\mathrm{Zn}$ accumulation in Orychophragmus violaceus. Appl Soil Ecol 44(1):1-5

126. Smith ME, Facelli JM, Cavagnaro TR (2018) Interactions between soil properties, soil microbes and plants in remnantgrassland and old-field areas: a reciprocal transplant approach. Plant Soil 433(1-2):127-145

127. Yahaya S, Aliyu I, Bello S (2019) Improvement of nodulation and nitrogen fixation of groundnut (Arachishypogaea $\mathrm{L}$ ) using pasture and grain legume rhizobia isolates in different soil management. Fudma Jaat 4(2):273-283

128. van Heerwaarden J, Baijukya F, Kyei-Boahen S, Adjei-Nsiah S, Ebanyat P, Kamai N, Wolde-Meskel E, Kanampiu F, Vanlauwe B, Giller K (2018) Soyabean response to rhizobium inoculation across sub-Saharan Africa: patterns of variation and the role of promiscuity. Agr Ecosyst Environ 261:211-218

129. Wolde-meskel E, van Heerwaarden J, Abdulkadir B, Kassa S, Aliyi I, Degefu T, Wakweya K, Kanampiu F, Giller KE (2018) Additive yield response of chickpea (Cicer arietinum L.) to rhizobium inoculation and phosphorus fertilizer across smallholder farms in Ethiopia. Agr Ecosyst Environ 261:144-152

130. Sanyal D, Osorno JM, Chatterjee A (2020) Influence of Rhizobium inoculation on dry bean yield and symbiotic nitrogen fixation potential. J Plant Nutr 1-13 
131. Acuña JJ, Jorquera MA, Barra PJ, Crowley DE, de la Luz MM (2013) Selenobacteria selected from the rhizosphere as a potential tool for Se biofortification of wheat crops. Biol Fertil Soils 49(2):175-185

132. Acosta J, Martínez-Martínez S, Faz A, Arocena J (2011) Accumulations of major and trace elements in particle size fractions of soils on eight different parent materials. Geoderma 161(1-2):30-42

133. Nunan N, Wu K, Young IM, Crawford JW, Ritz K (2003) Spatial distribution of bacterial communities and their relationships with the micro-architecture of soil. FEMS Microbiol Ecol 44(2):203-215

134. Carson JK, Gonzalez-Quiñones V, Murphy DV, Hinz C, Shaw JA, Gleeson DB (2010) Low pore connectivity increases bacterial diversity in soil. Appl Environ Microbiol 76(12):3936-3942

135. Chau JF, Bagtzoglou AC, Willig MR (2011) The effect of soil texture on richness and diversity of bacterial communities. Environ Foren 12(4):333-341

136. Whitman T, Neurath R, Perera A, Chu-Jacoby I, Ning D, Zhou J, Nico P, Pett-Ridge J, Firestone M (2018) Microbial community assembly differs across minerals in a rhizosphere microcosm. Environ Microbiol 20(12):4444-4460

137. Whitman T, Neurath R, Perera A, Ning D, Zhou J, Nico P, PettRidge J, Firestone M (2017) Microbial community assembly differs by mineral type in the rhizosphere. bioRxiv 128850

138. Poll C, Thiede A, Wermbter N, Sessitsch A, Kandeler E (2003) Micro-scale distribution of microorganisms and microbial enzyme activities in a soil with long-term organic amendment. Eur J Soil Sci 54(4):715-724

139. Totsche KU, Amelung W, Gerzabek MH, Guggenberger G, Klumpp E, Knief C, Lehndorff E, Mikutta R, Peth S, Prechtel A (2018) Microaggregates in soils. J Plant Nutr Soil Sci 181(1):104-136

140. Zhang P, Zheng J, Pan G, Zhang X, Li L, Rolf T (2007) Changes in microbial community structure and function within particle size fractions of a paddy soil under different long-term fertilization treatments from the Tai Lake region China. Colloids Surf B Biointerfaces 58(2):264-270

141. Chaudhry V, Rehman A, Mishra A, Chauhan PS, Nautiyal CS (2012) Changes in bacterial community structure of agricultural land due to long-term organic and chemical amendments. Microb Ecol 64(2):450-460

142. Hemkemeyer M, Dohrmann AB, Christensen BT, Tebbe CC (2018) Bacterial preferences for specific soil particle size fractions revealed by community analyses. Front Microbiol 9:149

143. Chen J, He F, Zhang X, Sun X, Zheng J, Zheng J (2014) Heavy metal pollution decreases microbial abundance, diversity and activity within particle-size fractions of a paddy soil. FEMS Microbiol Ecol 87(1):164-181. https://doi. org/10.1111/1574-6941.12212
144. Six J, Bossuyt H, Degryze S, Denef K (2004) A history of research on the link between (micro) aggregates, soil biota, and soil organic matter dynamics. Soil Tillage Res 79(1):7-31

145. Zhu Y-G, Gillings M, Simonet P, Stekel D, Banwart S, Penuelas J (2017) Microbial mass movements. Science 357(6356):1099-1100

146. Evans S, Martiny JB, Allison SD (2017) Effects of dispersal and selection on stochastic assembly in microbial communities. The ISME J 11(1):176-185

147. Thebo AL, Drechsel P, Lambin E, Nelson K (2017) A global, spatially-explicit assessment of irrigated croplands influenced by urban wastewater flows. Environ Res Lett 12(7):074008

148. Bengtsson-Palme J (2017) Antibiotic resistance in the food supply chain: where can sequencing and metagenomics aid risk assessment? Curr Opin Food Sci 14:66-71

149. UNWTO (2016) International tourist arrivals up $4 \%$ reach a record 1.2 billion in 2015. http://Media.unwto.Org/Press-relea se/2016-01-18/international-tourist-arrivals-4-reach-record-12billion-2015. Accessed Mar 2016

150. Joly K, Gurarie E, Sorum MS, Kaczensky P, Cameron MD, Jakes AF, Borg BL, Nandintsetseg D, Hopcraft JGC, Buuveibaatar B (2019) Longest terrestrial migrations and movements around the world. Sci Rep 9(1):1-10

151. Bengtsson-Palme J, Angelin M, Huss M, Kjellqvist S, Kristiansson E, Palmgren H, Larsson DJ, Johansson A (2015) The human gut microbiome as a transporter of antibiotic resistance genes between continents. Antimicrob Agents Chemother 59(10):6551-6560

152. Wilkinson BH, McElroy BJ (2007) The impact of humans on continental erosion and sedimentation. Geol Soc Am Bull 119(1-2):140-156

153. Tardy V, Mathieu O, Lévêque J, Terrat S, Chabbi A, Lemanceau P, Ranjard L, Maron PA (2014) Stability of soil microbial structure and activity depends on microbial diversity. Environ Microbiol Rep 6(2):173-183

154. Francioli D, Schulz E, Lentendu G, Wubet T, Buscot F, Reitz $\mathrm{T}$ (2016) Mineral vs organic amendments: microbial community structure, activity and abundance of agriculturally relevant microbes are driven by long-term fertilization strategies. Front Microbiol 7:1446

155. Sadet-Bourgeteau S, Houot S, Karimi B, Mathieu O, Mercier V, Montenach D, Morvan T, Sappin-Didier V, Watteau F, Nowak V (2019) Microbial communities from different soil types respond differently to organic waste input. Appl Soil Ecol 143:70-79

156. Le Guillou C, Chemidlin Prévost-Bouré N, Karimi B, AkkalCorfini N, Dequiedt S, Nowak V, Terrat S, Menasseri-Aubry S, Viaud V, Maron PA (2019) Tillage intensity and pasture in rotation effectively shape soil microbial communities at a landscape scale. MicrobiologyOpen 8(4):e00676 